\title{
Sustaining farmers livelihoods through community forestry in Sikka, East Nusa Tenggara, Indonesia
}

\author{
GERSON N. NJURUMANA ${ }^{1, \boldsymbol{\nu}}$, KIRSFIANTI L. GINOGA ${ }^{2}$, DONA OCTAVIA ${ }^{2}$ \\ ${ }^{1}$ Environment \& Forestry Research and Development Institute of Kupang. Jl. Alfons Nisnoni No. 7, Kupang 85115, East Nusa Tenggara, Indonesia. \\ Tel.: +62-380-823357, Fax.: +62-380-831068, "email: njurumana@gmail.com. \\ ${ }^{2}$ Forest Research and Development Center. Jl. Gunung Batu No. 5, Bogor 16610, West Java, Indonesia
}

Manuscript received: 27 May 2020. Revision accepted: 26 July 2020.

\begin{abstract}
Njurumana GN, Ginoga KL, Octavia D. 2020. Sustaining farmers livelihoods through community forestry in Sikka, East Nusa Tenggara, Indonesia. Biodiversitas 21: 3786-3796. One of the goals of managing global forest ecosystems today is to synergize their socio-economic, ecological and community livelihood benefits. Each forest type has various socio-economic and ecological characteristics that influence its management strategies and the provision services to the community. In general, the socio-economic benefits of forests in supporting community livelihoods are well known, however, the information which is specifically relevant to tropical monsoon forests is still very limited. This research aims to fill this knowledge gap, by providing information about the socio-economic conditions and provision of services of tropical monsoon forests to people's livelihoods. The research was conducted through structured interviews, FGDs, and field observations, by an analysis unit in community forests in the Sikka district. The information obtained was analyzed through descriptively qualitative and quantitative methods. The results showed an imbalance between the socio-economic conditions of people who rely on the tropical monsoon forest for their livelihoods and the carrying capacity of fuelwood, food, and fodder supply. This imbalance is due to the weak synergy and organization of stakeholders in optimizing how the provision services of forests are used to support farmers' livelihoods. Farmers' dependence on the tropical forest services is still high, therefore the strengthening of farmers' institutions becomes a key factor that determines sustainable management of the forest and enhances the value of its benefits to the community.
\end{abstract}

Keywords: Fuelwood, food, fodders, tropical monsoon-forest

\section{INTRODUCTION}

Enhancing forests based on economic, social, and environmental benefits, including by improving the livelihoods of people who depend on forests, is one of the Global Forest Goals (GFGT, 2019). Forests provide livelihoods to humans, especially among poor village areas in developing countries (Twala 2012; FAO 2015; Rasmussen et al. 2017). These communities are very dependent on the availability of material resources from forests for their daily needs (Babulo et al. 2009; Barbier 2010; Rasmussen et al. 2017; Ali \& Rahut 2018; Damania et al. 2020). Forests provide various benefits to the community, including food, animal feed, water, energy, health, and spirituality (MEA 2005; Fisher et al. 2010 Hogarth et al. 2013; Angelsen et al. 2014; Wunder et al. 2014; Lee et al. 2015; Dash et al. 2016; Nepal et al. 2017; Ali and Rahut 2018; Chow 2018; Koffi et al. 2018; Barua et al. 2020; Umaya et al. 2020). Well-managed forest resources are a source of income for rural communities, with an income contribution of $17-45 \%$ - at an average of 22\% (Vedeld et al. 2007; Babulo et al. 2009; Nielsen et al. 2012; Oli et al. 2016; Angelsen et al. 2014; Ali et al. 2020) Furthermore, sustainable management of forest resources has a role in reducing poverty (Shackleton et al. 2007; Ali and Rahut 2018).

Efforts to reduce poverty around forest areas are required because impoverished areas contribute directly to increased deforestation (Tsujinoa et al. 2016; Miyamoto
2020). FAO (2015) reported that $25 \%$ of the world's population rely on forests for their livelihoods, including 48.8 million Indonesians who live in state forests (Wollenberg et al. 2004). 10.2 million of these people are classified as poor (Brown 2004). The existence of communities around forest areas influences the dynamics of forest management policies in Indonesia. Currently, as many as 8,643,228 households live around forest areas, $2.81 \%$ of which are practicing shifting cultivation (BPS 2018).

Indonesia has various forest types, one of which is the tropical monsoon forests, which have a wide distribution. This type of forest is a strategic resource in forestry development. The government encourages the development of the forestry sector as one of the solutions to alleviate poverty in communities surrounding the forest. Social forestry policies are carried out through several forest area utilization schemes (Erbaugh 2019; Rakatama and Pandit 2020), one of which is Community Forestry (CF), which aims to provide space for participation of the community in managing forests. Tropical monsoon forest areas are one of the loci used in the development of social forestry, but there is no specific information on the carrying capacity of these areas in relation to community's livelihoods. This is needed because there are 2,308 $(70.58 \%)$ poor villages inside and around the forests in East Nusa Tenggara (NTT) province. Many of these communities are experiencing socio-economic limitations, as indicated by the fact that 
$59 \%$ have low per capita expenditure and $78 \%$ have low education levels (BPS 2016).

Tropical monsoon forests have a high ecological vulnerability due to the pressures of climate change and fires, and require great efforts to be restored (Hamilton et al. 2020). Forest destruction has implications for the loss of potential income and the cost needed to rehabilitate those who lose their livelihoods (Barua et al. 2020). On the other hand, the value of traditional forest usage for communities is estimated at only $1.36 \%$ of the total value of forest ecosystem services (Kibria et al. 2017). Forest characteristics affect the value of the forest ecosystem services produced, and information about them is still very limited and thus has not yet aided in the formulation of specific management policies. This has led to research on tropical monsoon forests that are managed as sites for the development of social forestry. The important question in this research is what is the socio-economic reality of the people who depend on tropical monsoon forests, and how valuable are the benefits of providing forest services?. This question led in this study to an analysis of the socioeconomic conditions of the village, the quality of human resources, income and expenditure of farmers, community perceptions, and the management and use of forests for fuelwood, food, and animal feed by farmers in Tuartana CF, Sikka District.

\section{MATERIALS AND METHODS}

\section{Study area}

Tuartana CF is located in Hikong Village, Talibura Subdistrict, Sikka District, East Nusa Tenggara Province, Indonesia (Figure 1). CF covers an area of 246.88 ha $(2.07 \%)$ of the total IUPHKm (Community Forest Utilization Permit) in the Sikka District, which covers an area of 16,775 ha. The entire area of Tuartana CF lies in the protected forest area of Wukuh Lewoloroh RTK 126, at latitude $08^{0} 30^{\prime} 47^{\prime \prime}-08^{0} 32^{\prime} 58^{\prime \prime}$ South and $122^{0} 38^{\prime} 10$ " $122^{\circ} 40^{\prime} 16^{\prime \prime}$ East, at an elevation of 500-975 m above sea level. This area has undergone degradation, with open land cover measuring $35.83 \%$ of the total area, high-density vegetation cover measuring $34.68 \%$, and low-density vegetation cover measuring $29.48 \%$ (RKU 2017). The CF area, which is covered by fields and low-density vegetation, is used as farmland by 227 households involved in managing CF. This community involvement is expected to help encourage improved management and forest cover. The area with high-density vegetation cover is maintained as a biophysical protected area. Soil types at this location consisted of humic cambisol, covering 192.50 ha $(55 \%)$ and district cambisol, covering 154.38 ha $(45 \%)$. Based on topographic studies, an area of 132.54 ha $(38 \%)$ consisted of steeply sloping land, 107.32 ha $(31 \%)$ consisted of slightly steep land, 80.13 ha $(23 \%)$ consisted of flat land 26.68 ha (8\%) was classified as very steep (RKU 2017).
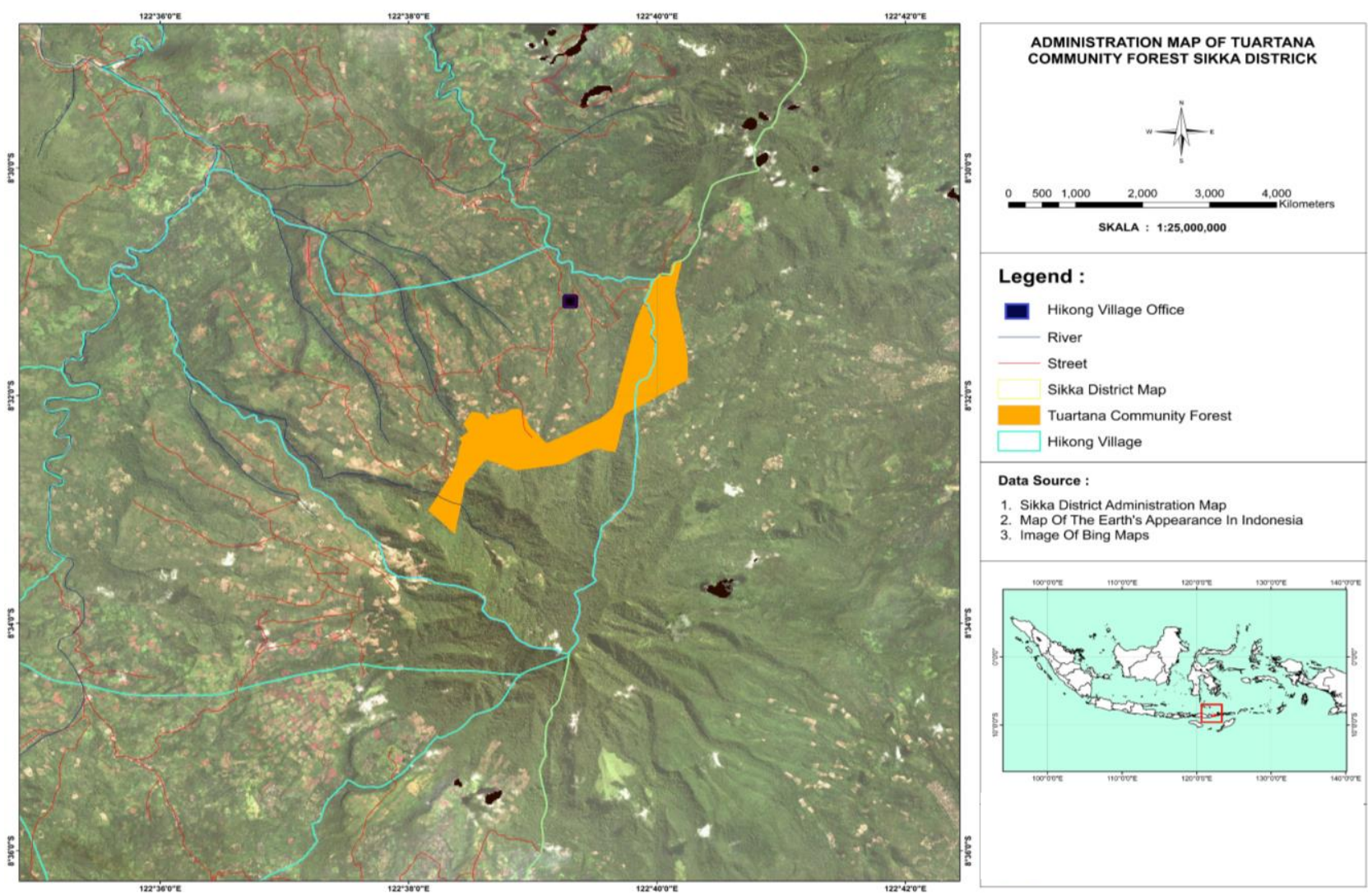

Figure 1. Tuartana community forest in Sikka District, East Nusa Tenggara, Indonesia 


\section{Procedures}

The research in this study consisted of 3 main activities. Firstly, we collected secondary data from government institutions, in the form of Hikong Village Statistics, Sikka District Statistics, Sikka Forest Management Unit (FMU) statistics, and NTT Province statistics. Secondary data collection was carried out to analyze the socio-economic conditions of the community, including the number of households involved in $\mathrm{CF}$, land productivity, processing, and income per capita. Furthermore, we collected primary data from farmers in the village. This was conducted to determine the socio-economic conditions of farmers involved in managing CF. Data and information collected included management initiation, area of arable land, the usage of firewood, food, animal feed, the accessibility to forest areas, and the income and expenditure per capita. We also carried out a community survey on several aspects relevant to managing $\mathrm{CF}$. Thirdly, we conducted field observations on 21 units of farmland samples in $\mathrm{CF}$ locations, spread over 3 management blocks. These field observations were intended to confirm the data and information obtained during the interview at each farmer's house.

The respondents in this study were members of the Tuartana CF farmer group. Socio-economic data collection was carried out on a sample of farmer households involved in managing CF. Determination of respondents was carried out in phases with a simple random sampling method. The sample of farmers was 35 households (15\%) out of 227 households involved in managing $\mathrm{CF}$, including $10(4 \%)$ as representatives of households led by women. Determination of the criteria of respondents refers to several criteria that were used in the selection of respondents (Njurumana et al. 2014; Njurumana 2016). Surveys and interviews were carried out in parallel at farmhouses, discussing with the head of the household together with family members. In addition, we conducted in-depth interviews and focus group discussions (FGDs) with the leaders of the $\mathrm{CF}$ farmer groups, traditional leaders, and other farmer group members. In a cultural sense, the interview approach of collecting this data within the village can be very beneficial. The traditions of the local community prioritize friendship, to ensure that emotional relationships with farmers and their families are maintained. Therefore, collecting data directly within the village means that the information obtained is more detailed, and bridges the limitations of farmers in terms of literacy. The researchers were directly involved in the collection of data and were assisted by staff from the Sikka FMU and management from the CF farmer group.

\section{Data analysis}

Data and information analysis were carried out qualitatively on socio-economic aspects, education and farmers' perceptions of managing $\mathrm{CF}$, household income, and on the analysis of the forest resource value contributions to the livelihoods of CF farmers.

\section{RESULTS AND DISCUSSION}

\section{Socio-economic conditions}

Description of Hikong Village residents

Hikong Village is one of 2,308 villages around the forest area in NTT, and has a population of 2,196 people spread over 504 households. Dryland farming, which includes activities such as collecting forest products and conventional livestock farming, is the main source of income for $95 \%$ of households in the village. The number of people working in the dryland agriculture sector is higher than the average for households who work in this sector in the Sikka district 65\% (BPS 2015), and NTT province $61 \%$ (BPS 2016). In general, the farming system carried out is still conventional, with limited financial input, knowledge, expertise, skills, and land area.

Land is one of the main factors affecting production in dryland farming. The size of farmland managed by farmers is still limited by conventional management. This is proven by as many as $97 \%$ of households owning farmland in the area range of $0.1-0.2 \mathrm{ha} / \mathrm{HH}$ or $0.025-0.05 \mathrm{ha} /$ capita, which is below the average minimum requirement for subsistence farming (Susilowati and Maulana 2012). Low land production means that the welfare of farmers has not undergone significant changes. Farmers experience multidimensional limitations, including low value land assets, limited education and a lack of farming innovation. Therefore, this has an impact on land management and productivity, as well as the economic resilience of farmers, which contributes to increasing poverty levels. As many as 2,186 people $(99.54 \%)$ in Hikong Village were described as living in poverty. Low land productivity also has implications for food security, meaning as many as 305 households $(60.51 \%)$ are recipients of poor rice (Raskin) assistance from the government. The largest pre-prosperity (pra-sejahtera) group is women, with 1,272 people (58\%). They can become very vulnerable if the management of forest resources is not carried out sustainably.

CF farmers belong to economically vulnerable groups, with 227 families from pre-prosperity families using forest land for dryland farming. Additional farmland through $\mathrm{CF}$ has not increased productivity, meaning there is no significant difference in socio-economic conditions between farmers involved or uninvolved in the $\mathrm{CF}$ program. The main obstacle is that additional farmland through $\mathrm{CF}$ has not been followed by facilitation activities for more professional management. The farming patterns applied are still conventional, whereas the accompaniment and extension activities from government institutions has not been provided.

Farmers have not yet become involved in the management of Non-Timber Forest Products (NTFPs) on $\mathrm{CF}$ land. Generally, they play a dual role as farmers, collectors of forest products and breeders, meaning farmers' welfare has not experienced significant changes. The welfare indicator was approved by Hikong Village statistics, which reported 498 households (99\%) inhabited very simple houses with walls made of woven bamboo. Furthermore, as many as 297 households (58.92\%) 
inhabited community houses with cement floors. Both of these figures are higher than the average value for the Sikka district and NTT provinces (BPS 2015). The socioeconomic condition of these farmers is an illustration of the general state of community poverty in the villages around and within the forest area in NTT.

\section{General description of Tuartana Community Forestry}

The legality of managing CF is influenced by Minister of Forestry Decree No.388/Menhut-II/2010, which regulates the establishment of Egon Ilimedo and Wukoh Lewoloroh protection forest areas covering an area of 16,755 ha as CF working areas. Subsequently, the forest utilization permit (IUPHKm) from the Sikka District Head No.: $127 / \mathrm{HK} / 2012$ covering an area of 346.88 ha was divided into three management blocks, namely Hikong, Natargahar, and Natarmude. Each management block is dominated by steep and very steep land topography, meaning caution is needed in its management so that damage is not caused. Utilization of land for food crop cultivation requires the addition of soil and water conservation inputs to mitigate surface damage. Steep topography conditions limit the accessibility of farm roads and the mobilization of produce from CF land. Therefore, the mobilization of produce is very dependent on manual human labor, with the distance to the farmers' settlements often being the furthest that product is able to be moved. This condition needs to be addressed by stakeholders to strengthen integrated multi-sector coordination in intervening land use planning and supporting infrastructure. Local governments need to pay special attention to building synergy in unraveling biophysical constraints that have a direct impact on reducing the production capacity and community income from CF land farming.

\section{Human resources}

Poverty of $\mathrm{CF}$ farmers is a reflection of their limited access to formal education. The level of formal education varies, with as many as $74 \%$ reaching primary school level, $15 \%$ reaching junior high school level, and $11 \%$ reaching senior high school level (Hikong Village Profile 2017). Communities around forest areas have difficulty in accessing educational institutions, including opportunities to attend training and teaching. This results in a great difference between education levels in village areas and education averages at district and provincial levels (BPS 2016). Quality of human resources involved in managing $\mathrm{CF}$ is one of the challenges in optimizing forest management and community economic development. Limited knowledge of farmers has a direct implication on their weak bargaining power during negotiations on management, utilization, product diversification, and marketing. Therefore, giving access to land use through $\mathrm{CF}$ needs to be supported in a structured and sustainable way, with the input of training and infrastructure programs. Empowerment of CF farmers becomes a deciding factor in managing and utilizing forest resources efficiently, effectively, and competitively to support forest management goals.

\section{Income and expenditure}

The income and expenditure of farmers are an output of their ability to produce goods and services. The low ability of farmers to do this has implications for development in the management of potential forest resources, product diversification, and marketing networks. This limitation contributes to the low income per capita of farmers, with an average of IDR. 276,950/month. This value is lower than the poverty line threshold in NTT province of IDR 401,220/month (BPS 2018). In general, the level of welfare of farmers is still below the average poverty threshold at both local, national, and global levels.

Household expenditure is one welfare indicator that is influenced by the value of income. The average farmer's per capita expenditure is IDR 150,550 /month, far lower than the average from the Sikka district of IDR $634,800 /$ month, and the average from NTT province of IDR 681,450/month (BPS 2018). The main purpose of farmers' expenditure is to buy basic necessities such as food. To reduce food expenditure, one of the strategies carried out by farmers is to enrich the CF land with food sources such as paddy fields and tubers. These efforts have not yet been followed by management innovations, meaning land productivity is still low, and this has encouraged farmers to source food from outside the village.

Limited accessibility to farmland affects farmers' income and expenditure. The potential from forest resources on $\mathrm{CF}$ land is sufficiently available, but it is constrained by the low accessibility for the mobilization of produce, meaning it has not yet made a real contribution to increasing farmers' income and expenditure. Therefore, mobility of farming produce from production sources to human settlements depends on the strength of the farmers. In addition, some commodities have high costs and are perishable during transportation over long distances to trade centers. This means that a number of key commodities produced such as candlenut, tamarind, cashew, pineapple, and cassava have not provided significant increases to farmers' incomes.

The low income and expenditure per capita of farmers gives an indication of the high poverty rate of the people living around the forest. The high potential of forest resources does not guarantee an increase in community welfare, as long as collaboration across sectors is still low. Poverty in CF farmers is a reflection of the poor synergy and collaboration of stakeholders in helping farmers to manage the potential of forest resources. The role of the local government is needed, especially for empowerment and for offering community assistance programs. Decree of NTT Governor No. 404/KEP/HK/2018 concerning superior NTFPs is expected to be an entry point for parties to collaborate and encourage integrated cultivation programs in forest areas. This regulation encourages farmer group partnerships with BUMDes (Village-Owned Enterprises), BUMD (Regional-Owned Enterprises), and other strategic partners to improve the development of superior commodities such as cashew, tamarind, candlenut, areca nut and betel in Sikka (Njurumana and Octavia 2020). 


\section{Community perception}

There is a deepening understanding among villages of the CF importance value, therefore the support of infrastructure is carried out together with farmers. Farmers' perceptions of $\mathrm{CF}$ characteristics are grouped into 5 (five) categories; very unimportant, unimportant, slightly important, important, and very important. Based on these categories, as many as $78 \%$ of farmers recognize that $\mathrm{CF}$ permits are very important and $22 \%$ recognize that permits are important in supporting the availability of farmland for communities. Farmers realize that the existence of CF has direct benefits as a source of food, fuelwood, animal feed, medicinal plants, and NTFPs. This awareness provides an opportunity to synergize community empowerment programs with forest conservation, especially in regards to building strong partnerships with village institutions to support the active participation of farmers in the rehabilitation and conservation of forest areas. One example of this strategy is the development of superior NTFPs. Farmers recognize and appreciate that village institutions have a strategic role in encouraging the management and use of CF. Surveying of farmer perceptions showed that $56 \%$ stated that the role of village institutions is slightly important, $41 \%$ stated that it was important and $4 \%$ of farmers stated that it was very important. Village institutions play a role in encouraging and facilitating the participation of farmers in the management and utilization of CF land, which can help with conflict mitigation that might occur among farmer groups.

Poor conditions occur in terms of infrastructure and accessibility to trade centers, extension institutions, financial institutions, and transportation. The majority of farmers (52\%) stated that access to these institutions was classified as very low (bad), with $48 \%$ stating that it was low. These perceptions are in line with the facts, with the majority of areas suffering from limited and high-cost transportation facilities, particularly in farm areas that are further from the village. This condition needs to become a focus of policymakers to provide service solutions to the community around CF locations. In addition, it is necessary to strengthen village institutions as facilitators to encourage regular meetings between $\mathrm{CF}$ farmers and partner institutions such as BUMDes and cooperatives. This will help to build cooperation in overcoming technical obstacles in the distribution and marketing of CF products.

The socio-economic reality of the community is an important input that needs attention in forest management. Optimizing the management of forest resources for poverty reduction is determined by the quality of human resources. Forest resource management is expected to play a role in reducing poverty, which is a major challenge for the global community today, making it the first priority for the SDGs (Liu and Li 2017; Malerba 2020; Xu et al. 2020). Poverty has a multidimensional impact, with one effect being an increase in the rate of deforestation, which can result in further economic losses (Yamamoto et al. 2019; Miyamoto 2020; Phimmavonga and Keenan 2020; Edwards et al. 2020). Degraded forests will limit the choice of potential livelihoods, especially in terms of the materials and benefits provided by the forest (Nerfa et al. 2020; Ahmed and Gasparatos 2020). Conservation efforts and community access to biodiversity around forests can facilitate welfare improvements (Ali and Rahut 2018; Mammides 2020; Miller and Hajjar 2020). Therefore, it is important that the economic value of land managed by farmers in various forest use schemes is considered as an investment, because forest land is of strategic value as a trigger for economic empowerment (Nielsen et al. 2012) and the fulfillment of basic needs and community welfare (Sewel et al. 2020).

\section{Management and utilization of community forestry \\ Management of community forestry}

Management is a systematic effort to achieve a goal. The determining factor for achieving management objectives is the availability of strategies and program input (Ekawati et al. 2018). The management of CF is not yet optimal due to the lack of knowledge, technology, information, and institutional input of farmers. Innovations in the use of farmland such as spatial planning for food crop cultivation and long-life plants for NTFPs have not been properly managed. This means the landscape is dominated by only a few plant species, one of which is candlenut (Aleurites moluccana L. Willd), which covers $65 \%$ of CF management area (RKU 2017). The irregular structure and composition of plants have implications for the availability of nutrients for plant growth. Only plant species that are able to adapt will get optimal benefits to support their production, while other plants will be unable to grow. This has led to a decline in the productivity of food crops and fruits in recent years in the community. Therefore, assistance is needed for the spatial use of land and crop regeneration, including the possibility of increasing the arable land area available to farmers who have succeeded in carrying out rehabilitation and reforestation on critical CF land.

Appropriate spatial arrangement and land additions are needed because the area of CF land managed by farmers tends to remain stable, while the number of CF farmer family members tends to increase by $0.3 \%$ /year (BPS 2015). Therefore, social problems are likely to appear because the average area of farmland is only available at $0.3 \mathrm{ha} /$ capita, which is not enough to sustain a growing population. This problem requires serious assistance, with the aim of intensifying management to increase land productivity, while avoiding the expansion of plantation land into protected forest areas. Limited land area has also increased urbanization, encouraging young people in villages to find work in urban areas, the service sector, and to work abroad.

The management of $\mathrm{CF}$ aims to guarantee the sustainability of forest resources through community empowerment. Exactly how community participation will change in the future is an important question in managing CF. Farmer participation through reforestation of NTFP species has led to an increase in forest cover, and the development of NTFP commodities has implications for increasing the number of commodities available as a source of income for farmers. This behavior will maintain the balance of forest management benefits and their impact on 
improving farmers' livelihoods, so that the effect of forest benefits on poverty alleviation can be increased. Efforts to improve the benefits of forests to communities require concrete action, because many cases show that even though the potential for providing forest resources is high, it is not yet directly proportional to efforts to improve community welfare (Fischer et al. 2008; Pearce 2011; Kangalawe and Noe 2012). This is due to the fact that the basis for spatial planning of forest management has not been optimal and the ability of farmers to diversify and increase the value of forest products is still low. Action is needed to encourage species that help to improve conservation strategies, increase land cover, and improve community welfare, and this represents one of the long-term management solutions for $\mathrm{CF}$.

The intensification of NTFP commodities has been started by some farmers managing CF. The main obstacle to this is the limited area of farmland, which means that the planting of NTFPs and food plants cannot be done in large quantities. Farmers plant in the rainy season, with an intensity of 2 times/year. The average planting activity is 21 trees for NTFP commodities, and 46 trees for food commodities. NTFPs include candlenut (Aleurites moluccana L. Willd 1805) and cashew (Anacardium occidentale L.). Food crops include cassava (Manihot esculenta Crantz), sweet potato (Ipomoea batatas L.), suweg (Amorphophallus campanulatus BI), gembili (Dioscorea esculenta L.), avocado (Persea americana L.) and banana (Musa paradisiaca L.). Planting activities are adjusted to the availability of growing space, the availability of plant seeds, and the opportunities different plants offer for enrichment and replanting. For example, the planting of key cultural species such as areca nut (Areca catechu L.) and betel (Piper betle L.) increases biodiversity while also providing benefits to the community (Njurumana et al. 2014; Njurumana 2016; Njurumana 2019; Njurumana and Octavia 2020). Ekawati et al. (2018) said that a management policy must represent 3 (three) key elements, namely goals, strategies to achieve these goals, and operational inputs to drive the strategy. CF management policies have not yet fully implemented policy instruments that support management objectives. The main obstacle to this lies in the availability of inputs to support management strategies, such as Business Work Plans (RKU) and Annual Work Plans (RKT), which were only available at the end of 2017, meaning field assistance activities only started in 2018.

\section{Utilization of community forestry}

There are various benefits to providing services from the forest to support people's lives, especially in the availability of resources used as a source of fuelwood, food, and animal feed. Providing CF services to the community is very important in building household resilience and reducing expenditure per capita.

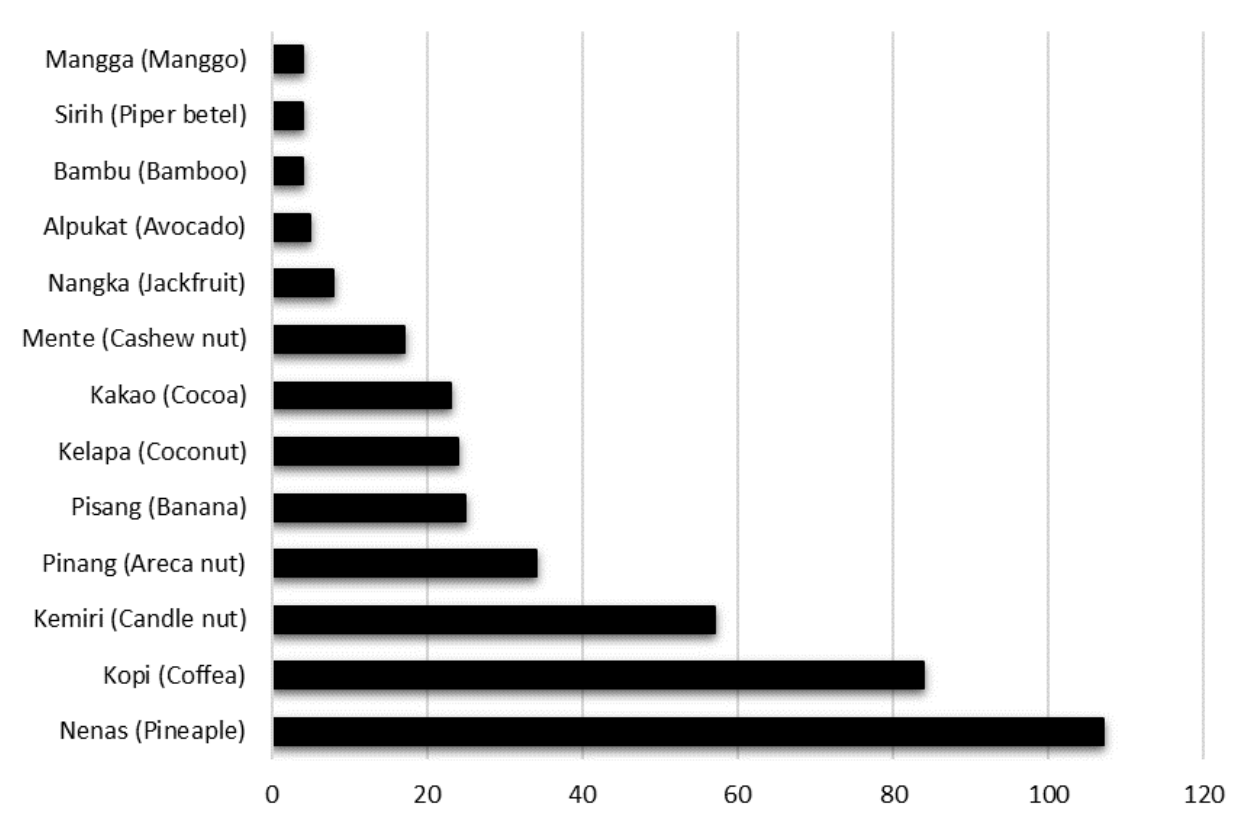

Figure 2. Averages number of trees as main commodity on Tuartana Community Forestry area (unit land management) 


\section{Provision of fuelwood}

Fuelwood is a basic requirement of village communities (Jose 2012; Lee et al. 2015), as proven by the fact that all Hikong Villagers use wood for fuel. At a provincial level, fuelwood usage is carried out by $68.42 \%$ of people and in Indonesia, as a whole, the figure is $32.23 \%$ (BPS 2012). CF areas are a key source of fuelwood, with $74 \%$ of households using it, at an average contribution of $49 \%$ to household needs. This is lower than the contribution of Mutis Protected Forest, which reaches $87.45 \%$ (Dako et al. 2018). The average consumption of fuelwood in farmer households is $1.68 \mathrm{~m}^{3} / \mathrm{capita} / \mathrm{year}$, and the contribution of CF is 0.54 $\mathrm{m}^{3} /$ capita / year. Overall, CF contributed to meeting the demand for as much as $460.08 \mathrm{~m}^{3} / y e a r$. The fuelwood used by farmers originates mostly from excess wood or fallen tree branches. Cutting down species of kaliandra (Calliandra calothyrsus Meissn), gamal (Gliricidea sp.), lamtoro (Leucaena leucocephala (Lam.) De Wit.) and bamboo (Bambusa sp.) in the CF location was mostly due to the regulation of growing space and the need for fuelwood. Fuelwood is used for carrying out various activities in CF locations, or for increasing fuel stocks in house yards and gardens.

Improving access to $\mathrm{CF}$ has given legitimacy to the use of fuelwood in the community, while management regulations ensure that usage is more selective, efficient, and effective. This regulation controls the balance between fuelwood fulfillment for poor people (Yang et al. 2020) with the fulfillment of global responsibilities of increasing forest cover, reducing gas emissions and storing carbon (Lecocg et al. 2011). This highlights the need to cultivate species of fuelwood producers with high calorific values, while also setting utilization quotas and guaranteeing legal certainty for violations (Jumbe and Angelsen 2011; Caurla et al. 2013). Therefore, plantation of high economic value NTFP commodities needs to be increased, as a substitute for community income sources derived from the sale of fuelwood (Mukul 2016; Uprety et al. 2016; Hussain et al. 2019). This mechanism helps protect high conservation value wood species not used as fuelwood, so they can support carbon sequestration and climate change mitigation (Kongsager and Corbera 2015; Jasaw et al. 2017; Tamang et al. 2019; Aggarwal and Brockington 2020).

\section{Provision of food}

Food from the cassava family and fruits are two of the main services from the forest that are utilized by the community. Several species of cultivated sweet potatoes have high nutrition and calories, including the cassava (Manihot esculenta Crantz) with a nutritional value of 146 calories and 34.7 grams of carbohydrate/100 grams (Suprapti 2005), sweet potatoes (Ipomoea batatas L.) with 135 calories and 31.8 grams of carbohydrates/100 grams (Juanda and Cahyono 2000), taro (Colocasia esculenta (L.) Schott) with a nutritional value of 120 calories and 28.2 grams of carbohydrate/100 grams, suweg (A. campanulatus BI) with 120 calories and 28.2 grams of carbohydrate/100 gram (Slamet and Tarkotjo 1980), and gembili (Dioscorea esculenta L.) with 470 calories/100 gram (French 2006). The production of several cassava species contributes $48 \%$ of the food consumed by CF farmers. Farmers' families consume $6.52 \mathrm{~kg} / \mathrm{capita} / \mathrm{month}$, and CF contributes 2.46 $\mathrm{kg} / \mathrm{capita} / \mathrm{month}(37.69 \%)$. Overall, $\mathrm{CF}$ production contributes as much as $25,151 \mathrm{~kg} /$ year to the food needs of farmers' families. The main contributor was cassava, which contributed $41.39 \%$, sweet potato contributed $31.73 \%$ and taro contributed $26.78 \%$.

Food sources from fruits come from banana (Musa paradisiaca), pineapple (Ananas comosus (L.) Merr), coconut (Cocos nucifera), mango (Mangifera indica L.) and jackfruit (Artocarpus integra). Pineapple is one of the main commodities cultivated by farmers, with a potential of 10-150 clumps/household. Pineapple production is quite high, but it is constrained by marketing - only $15-30 \%$ of the total production can be marketed and often sells at low prices. Food production from other fruit groups has not been measured by farmers, because populations of longtailed ape pests (Macaca fascicularis Raffles, 1821) are very high. These pests contribute to reducing the potential for food and fruit harvests, thereby affecting the value of their benefits to farmers.

Overall, the role of forest ecosystems in providing food for humans, both on a local and large scale cannot be ignored. Various forest management schemes within the community prove that forest provision services have a strong relationship with village livelihoods. Parajuli et al. (2015) proved that the development of food crops under shade of forest plants had an impact on improving the welfare of 450 million people in Asia. This illustrates that the food insecurity that occurs has a strong relationship with the rate of deforestation, and requires a strong strategy to synergize forest conservation efforts and increase food security (Paudel 2018; Andrieu et al. 2019), including the development of functional food plant species in an environmentally friendly way (Bahar et al. 2020). Furthermore, forest protection will have implications for the sustainability of ecosystem services that support food productivity (Vira et al. 2015; Sunderland et al. 2019; Mutaqin et al. 2020) and will encourage the many benefits forests provide to humans and the environment.

\section{Provision of animal feed}

Livestock is a significant economic asset for village communities, and are used for money, socio-cultural and religious affairs. All CF farmers acknowledged that they have and are currently raising livestock such as pigs and goats, and need a continuous supply of animal feed. CF land is a relatively high source of feed material, with $74 \%$ of farmers utilizing forest areas to meet the average animal feed requirement of $129.63 \mathrm{~kg} /$ month. Of this figure, $\mathrm{CF}$ land contributes $56.80 \mathrm{~kg}(43.82 \%)$. Overall, the management of $\mathrm{CF}$ land contributes directly to feed supplies of at least 107,434 kg/year. Animal feed production supports farmer incomes and ensures that livestock receive a sufficient amount of food, so that growth is normal, ensuring communities can participate in socio-cultural activities such as traditional rituals. Improved accessibility in the future will have a positive impact on increasing the production of animal feed in $\mathrm{CF}$, along with increasing the development of feed-in gardens 
and house yards, reducing the dependence on forests and supporting biodiversity conservation (Tamang et al. 2019). Through adequate technological input support, it is expected that the cultivation of animal feed on CF land, gardens and yards will promote land conservation, erosion control and soil fertility (Hoogmoed et al. 2012; Franzel et al. 2014; Das et al. 2016; Giday et al. 2018; Ahammada et al. 2019). Management of growing areas is needed to regulate the zonation balance of animal feed development with the demand for human food crops. This needs to take into account the sustainability of the forest ecosystem (Lusiana et al. 2012; Hoogmoed et al. 2012), while also avoiding weeds that adversely affect animal feed management (Khana et al. 2014).

The main finding of this research is that there is a correlation between institutional functions and social organizing in supporting the achievement of $\mathrm{CF}$ management objectives at a community level. Institutionally, the legality of managing $\mathrm{CF}$ has been addressed for a long time by the central government, but has not received serious attention from local governments (provincial and district) as stakeholders. This has resulted in interventions and collaborations in cross-sectoral management programs that have not been running as they should, resulting in long periods of inactivity. Furthermore, social organization among members of farmer groups is still weak, as a result of the low capacity of human resources, low household incomes, and poor social networking. This results in the bargaining power of farmers being very weak, and means that the initiation of community-based CF management programs often does not go as expected. The dynamics of managing $\mathrm{CF}$ are changing slowly, and require significant breakthroughs to achieve management goals through multi-stakeholder collaboration in the future. Collaboration is a key factor to build synergy, so that the potential for CF can be developed to encourage improvements in community welfare (Dupuitsa and Ongolob 2020; Du-Pont et al. 2020). To encourage collaboration, the main priority is to break down coordination barriers, then work together to facilitate programs at the farmer and institutional level, including removing obstacles to the application of CF (Poudel 2019).

Other findings from this research relate to the services provided by tropical monsoon forest ecosystems to support community livelihoods. Tropical monsoon forest ecosystems have different characteristics from wet tropical forest ecosystems, and have important implications for service provision to the community. The value of forest contribution becomes preliminary information to help understand the carrying capacity of the tropical monsoon forest ecosystem and its affect on the livelihoods of people living around the forest. This information helps stakeholders to create policies that prepare CF management plans and to help identify biodiversity that is sociallyculturally and ecologically appropriate to be developed in the tropical monsoon forest ecosystem in Indonesia.

Social forestry programs within $\mathrm{CF}$ in the monsoon tropical forest area needs to take into account the socioeconomic vulnerability of the community and the ecological vulnerability of the surrounding forest area.
Socio-economic vulnerability related to the condition of human resources and community welfare is classified as very low, and requires intervention to increase its capacity to support the management and utilization of forest resources efficiently, effectively and sustainably. Ecological vulnerability is related to the vulnerability of tropical monsoon forest ecosystems, which are easily damaged and require a long time and a high cost for rehabilitation.

The results of this study provide an understanding of the relationship between the existence of tropical monsoon forest ecosystems and the socio-economic realities of the surrounding communities. The nature and characteristics of fragile tropical monsoon forests have direct implications for the sustainability of community livelihoods. Management of forest areas needs to be improved through better accessibility, post-harvest processing technology, product diversification, and improved marketing networks. In addition, inputs for the $\mathrm{CF}$ farmer empowerment program need to be more inclusive, so that they build synergy and collaboration across sectors to support the empowerment of the people involved in managing $\mathrm{CF}$. Capacity building is conducted through the transfer of cultivation technology and the management of spatial planning to help sustainably increase forest productivity. Strengthening the synergy of cross-sector programs in facilitating the process of transformation and economic growth of environmentally friendly communities is needed. This can be done by providing facilities and infrastructure for processing products, improving access to farm roads for the mobilization of produce, and the integration of $\mathrm{CF}$ farms at the level of BUMDes, BUMD, and cooperatives that encourage increased value and forest sustainability. In addition, access to management and the utilization of forest areas needs to be followed by cross-sectoral commitments to encourage institutional strengthening of farmers through programs that encourage the achievement of forest management goals and community empowerment. Poor people will impoverish their environment, and environments that become poor will only increase people's struggle with poverty. Therefore, increasing the value of forest benefits on a sustainable basis is the key to improving the livelihoods and welfare of communities around the forest.

\section{ACKNOWLEDGEMENTS}

The authors would like to express sincere gratitude to Asean-Korea Forest Cooperation Regional Project (AFoCO) for providing funding for the study under Regional Project Component 3 "Facilitating the Participatory Planning of Community Based Forest Management using Geographic Information System and Remote Sensing Technologies in Forest Resource Management in the Philippine, Indonesia, and Thailand. We would like to express sincere gratitude to acknowledge anonymous reviewers for their constructive contribution to improve the manuscript. All authors have been contributed equally to this work. 


\section{REFERENCES}

Aggarwal A, Brockington D. 2020. Reducing or creating poverty? Analyzing livelihood impacts of forest carbon projects with evidence from India. Land Use Pol 95: 104608. DOI: 10.1016/j.landusepol.2020.104608.

Ahammada R, Staceya N, Sunderland TCH. 2019. Use and perceived importance of forest ecosystem services in rural livelihoods of Chittagong Hill Tracts, Bangladesh. Ecosyst Serv 35: 87-98. DOI 10.1016/j.e coser.2018.11.009.

Ahmed A, Gasparatos A. 2020. Multi-dimensional energy poverty patterns around industrial crop projects in Ghana: Enhancing the energy poverty alleviation potential of rural development strategies. Energy Pol 137: 111123. DOI: 10.1016/j.enpol.2019.111123.

Ali A, and Rahut DB. 2018. Forest-based livelihoods, income, and poverty: Empirical evidence from the Himalayan region of rural Pakistan. J Rural Stud 47: 44-54. DOI 10.1016/j.jrurstud.2017.10.001

Ali N, Hu X, Hussain J. 2020. The dependency of rural livelihood on forest resources in Northern Pakistan's Chaprote Valley. Glob Ecol Conserv 22: e01001. DOI: 10.1016/j.gecco.2020.e01001.

Andrieu N, Blundo-Canto G, Cruz-Garcia G.S. 2019. Trade-offs between food security and forest exploitation by mestizo households in Ucayali, Peruvian Amazon. Agric Syst 173: 64-77. DOI: 10.1016/j.agsy.2019.02.007.

Angelsen A, Jagger P, Babigumira R, Belcher B, Hogarth NJ, Bauch S, Börner J, SmithHall C, Wunder S. 2014. Environmental income and rural livelihoods: a global comparative analysis. World Dev 64: S12 S28. DOI: 10.1016/j.worlddev.2014.03.006

Babulo B, Muys B, Nega F, Tollens E, Nyssen J, Deckers J. 2009. The economic contribution of forest resources use to rural livelihoods in Tigray, Northern Ethiopia. For Policy Econo 11 (2): 123-131. DOI 10.1016/j.forpol.2008.10.007.

Bahar NHA, Loa M, Sanjayaa M, Vianena JV, Alexander P, Ickowitza A, Sunderland T. 2020. Meeting the food security challenge for nine billion people in 2050: What impact on forests? Glob Environ Change 62: 102056. DOI: 10.1016/j.gloenvcha.2020.102056.

Barbier EB. 2010. Poverty, development, and environment. Environ Dev Econ 15 (6): 635-660.

Barua SK, Boscolob M, Animon I. 2020. Valuing forest-based ecosystem services in Bangladesh: Implications for research and policies. Ecosyst Serv 42: 101069. DOI: 10.1016/j.ecoser.2020.101069.

BPS. 2012. Statistics of Nusa Tenggara Timur Province. Badan Pusat Statistik, Kupang. [Indonesian]

BPS. 2015. Statistics of Sikka Regency. Badan Pusat Statistik, Sikka [Indonesian]

BPS. 2016. Statistics of Nusa Tenggara Timur Province. Badan Pusa Statistik, Kupang. [Indonesian]

BPS. 2018. Jumlah dan persentase rumah tangga di sekitar kawasan hutan yang melakukan perladangan berpindah. https: //www.bps .go.id/ dynamictable/ 2018/03/21/1291/jumlah-dan-persentase-rumahtangga-di-sekitar-kawasan-hutan-yang-melakukan -perladanganberpindah-2004-dan-2014. html. [Indonesian]

BPS. 2018. Regional Statistics of Nusa Tenggara Timur Province. Badan Pusat Statistik, Kupang. [Indonesian]

Brown T. 2004. Analysis of Population and Poverty in Indonesia's Forests. Natural Resources Management Program Report, Jakarta.

Caurla S, Delacote P, Lecocq F, Barkaoui A. 2013. Stimulating fuelwood consumption through public policies: An assessment of economic and resource impacts based on the French Forest Sector Model. Energy Pol 63: 338-347. DOI: 10.1016/j.enpol.2013.07.111.

Chow J. 2018. Determinants of household fuelwood collection from mangrove plantations in coastal Bangladesh. For Pol Econ 96: 83-92. DOI: 10.1016/j.forpol.2018.08.007

Dako FX, Purwanto RH, Faida LRW, Sumardi. 2018. Firewood and carpentry wood contribution to the communities of Mutis Timau protected forest, Timor Island. Jurnal Manajemen Hutan Tropika 24 (3): 166-174. DOI: 10.7226/jtfm.24.3.166. [Indonesian]

Damania R, Joshi A, Russ J. 2020. India's forests - Stepping stone or millstone for the poor?. World Dev 125: 104451. DOI: 10.1016/j.worlddev.2018.11.007.

Das A, Patelc DP, Lala R, Kumar M, Ramkrushna GI, Layek J, Buragohain J, Ngachan SV, Ghoshd PK, Choudhury BU, Mohapatra KP, Shivakumar BG. 2016. Impact of fodder grasses and organic amendments on productivity and soil and crop quality in a subtropical region of eastern Himalayas, India. Agric Ecosyst Environ 216: 274282. DOI: 10.1016/j.agee.2015.10.011.

Dash M, Behera B, Rahut DB. 2016. Determinants of household collection of non-timber forest product (NTFPs) and alternative livelihood activities in Similipal Tiger Reserve, India. For Policy Econ 73: 215-228. DOI: 10.1016/j.forpol.2016.09.012

Du-Pont T, Mandisa C, Vilakazi N, Thondhlana G, Velded P. 2020. Livestock income and household welfare for communities adjacent to the Great Fish River Nature Reserve, South Africa. Environ Dev 33: 100508. DOI: 10.1016/j.envdev.2020.100508.

Dupuitsa E, Ongolob S. 2020. What does autonomy mean for forest communities? The politics of transnational community forestry networks in Mesoamerica and the Congo Basin. World Dev Perspect 17: 100169. DOI: 10.1016/j.wdp.2020.100169.

Edwards RB, Naylor RL, Higgins MM, Falcon WP. 2020. Causes of Indonesia's forest fires. World Dev 127: 104717. DOI: 10.1016/j.worlddev.2019.104717

Ekawati S, Salaka FJ, Budiningsih K. 2018. Analysis on readiness of Yogyakarta forest management unit as sub-national public service agencies. Jurnal Analisis Kebijakan Kehutanan 15 (1): 1-18. DOI: 10.20886/jakk.2018.15.1.1-18.

Erbaugh JT. 2019. Responsibilization and social forestry in Indonesia. For Policy Econ 109: 102019. DOI: 10.1016/j.forpol.2019.102019.

FAO. 2015. Forest and poverty reduction. Food and Agriculture Organization of the United Nations, Rome. www.fao.org/forestry/livelihoods/en/.

Fischer R, Maginnis S, Jackson W, Barrow E, Jeanrenaud S, Ingles A, Friend R, Mehrota R, Farvar T, Laurie M, Oviedo G. 2008. Linking conservation and poverty reduction: landscape, people and power. IUCN-The World Conserv Union, Gland.

Fisher B, Polasky S, Sterner T. 2010. Conservation and human welfare: economic analysis of ecosystem services. Environ Resour Econ 48 (2): 151-159. DOI: 10.1007/s10640-010-9415-0

Franzel S, Kiptot E, Lukuyu B. 2014. Agroforestry: Fodder Trees. Neal K, Van Alfen (eds.). Encyclopedia of Agriculture and Food Systems. Academic Press, New York. DOI: 10.1016/B978-0-444-525123.00023-1.

French BR. 2006. Food plants of Papua New Guinea. A compendium. Revised edition. Bruce French, Burnie, Tasmania, Australia.

GFGT. 2019. Global Forest Goal and Targets. The United Nations Strategic Plan for Forest 2030. Department of Economic and Social Affairs, United Nations, New York.

Giday K, Humnessa B, Muys B, Taheri F, Azadi H.2018. Effects of livestock grazing on key vegetation attributes of a remnant forest reserve: The case of Desa'a Forest in northern Ethiopia. Glob Ecol Conserv 14: e00395. DOI: 10.1016/j.gecco.2018.e00395.

Hamilton R, Penny D, Hall TL. 2020. Forest, fire \& monsoon: investigating the long-term threshold dynamics of south-east Asia's seasonally dry tropical forests. Quat Sci Rev 238: 106334. DOI: 10.1016/j.quascirev.2020.106334.

Hikong Village Profile (Profil Desa Hikong). 2017. Desa Hikong, Kecamatan Talibura, Kabupaten Sikka, Provinsi Nusa Tenggara Timur. [Indonesian]

Hogarth NJ, Belcher B, Campbell B, Stacey N. 2013. The role of forestrelated income in household economies and rural livelihoods in the border-region of Southern China. World Dev 43: 111-123. DOI: 10.1016/j.worlddev.2012.10.010

Hoogmoed M, Cunningham SC, Thomson JR, Baker PJ, Beringer J, Cavagnaro TRC. 2012. Does afforestation of pastures increase sequestration of soil carbon in Mediterranean climates? Agric Ecosyst Environ 159: 176-183. DOI: 10.1016/j.agee.2012.07.011.

Hussain J, Zhou K, Akbar M, Khan MZ, Raza G, Ali S, Hussain A, Abbas Q, Khan G, Khan M, Abbas H, Iqbal S, Ghulam A. 2019. Dependence of rural livelihoods on forest resources in Naltar Valley, a dry temperate mountainous region, Pakistan. Glob Ecol Conserv 20: e00765. DOI: 10.1016/j.gecco.2019.e00765.

Jasaw GS, Saito O, Gasparatos A, Shoyama K, Boafo YA, Takeuchi K 2017. Ecosystem services trade-offs from high fuelwood use for traditional shea butter processing in semi-arid Ghana. Ecosyst Serv 27: 127-138. DOI: 10.1016/j.ecoser.2017.09.003.

Jose S. 2012. Agroforestry for conserving and enhancing biodiversity. Agrofor Syst 85: 1-8. DOI: 10.1007/s10457-012-9517-5

Juanda D, Cahyono B. 2000. Ubi Jalar Budidaya dan Analisis Usaha Tani. Kanisius, Yogyakarta. [Indonesian] 
Jumbe CBL, Angelsen A. 2011. Modeling choice of fuelwood source among rural households in Malawi: A multinomial probit analysis. Energy Econ 33: 732-738. DOI: 10.1016/j.eneco.2010.12.011.

Kangalawe RYM, Noe C. 2012. Biodiversity conservation and poverty alleviation in Namtumbo district, Tanzania. Agric Ecosyst Environ 162: 90-100. DOI: 10.1016/j.agee.2012.08.008.

Kibria ASMG, Behie A, Costanza R, Groves C, Farrel T. 2017. The value of ecosystem services obtained from the protected forest of Cambodia: The case of Veun Sai-Siem Pang National Park. Ecosyst Serv 26: 27-36. DOI: 10.1016/j.ecoser.2020.101069.

Khana N, Shabbir A, George D, Hassan G, Adkins SW.2014. Suppressive fodder plants as part of an integrated management program for Parthenium hysterophorus L. Field Crops Res 156: 172-159. DOI: 10.1016/j.fcr.2013.11.003

Koffi CK, Gazull L, Gautier D. 2018. Variability of household fuelwood consumption in a rural Sudano-Sahelian context in Burkina Faso. Energy Sustain Dev 47: 75-83. DOI: 10.1016/j.esd.2018.09.001

Kongsager R, Corbera E.2015. Linking mitigation and adaptation in carbon forestry projects: Evidence from Belize. World Dev 76: 132146. DOI: 10.1016/j.worlddev.2015.07.003.

Lecocg F, Caurla S, Delacote P, Barkaoui A, Sauquet A. 2011. Paying for forest carbon or stimulating fuelwood demand? Insight from the French Forest Sector Model. J For Econ 17 (2): 157-168. DOI: 10.1016/j.jfe.2011.02.011.

Lee SM, Kim YS, Jaung W, Latifah S, Afifi M, Fisher LA. 2015. Forests, fuelwood and livelihoods-energy transition patterns in eastern Indonesia. Energy Pol 85: 61-70. DOI: 10.1016/j.enpol.2015.04.030.

Liu Y, Li Y. 2017. Revitalize the world's countryside. Nature 548: 275. DOI: $10.1038 / 548275 a$

Lusiana B, Noordwijk MV, Cadisch G.2012. Land sparing or sharing? Exploring livestock fodder options in combination with land use zoning and consequences for livelihoods and net carbon stocks using the FALLOW model. Agric Ecosyst Environ 159: 145-160. DOI: 10.1016/j.agee.2012.07.006.

Malerba D. 2020. Poverty alleviation and local environmental degradation: An empirical analysis in Colombia. World Dev 127: 104776. DOI: 10.1016/j.worlddev.2019.104776.

Mammides C. 2020. Evidence from eleven countries in four continents suggests that protected areas are not associated with higher poverty rates. Biol Conserv 241: 108353. DOI: 10.1016/j.biocon.2019.108353.

MEA (Millenium Ecosystem Assessment). 2005. Ecosystem and Human Well-Being: Synthesis. Island Press, Washington, DC

Miller DC, Hajjar R. 2020. Forests as pathways to prosperity: Empirical insights and conceptual advances. World Dev 125: 104647. DOI 10.1016/j.worlddev.2019.104647.

Miyamoto M. 2020. Poverty reduction saves forests sustainably: Lessons for deforestation policies. World Dev 127: 104746. DOI: 10.1016/j.worlddev.2019.104746

Mukul SA, Rashid AZMM, Uddin MB, Khan NA. 2016. Role of nontimber forest products in sustaining forest-based livelihoods and rural households' resilience capacity in and around protected area: a Bangladesh study. Environ Plann Manag 59: 628-642. DOI: 10.1080/09640568.2015.

Mutaqin AZ, Kurniadie D, Iskandar J, Nurzaman M, Partasasmita R. 2020. Ethnobotany of suweg, Amorphophallus paeoniifolius: Utilization and cultivation in West Java, Indonesia. Biodiversitas 21 (4): 1635-1644. DOI: 10.13057/biodiv/d210444.

Nepal M, Nepal AK, Berrens RP. 2017. Where gathering firewood matters: Proximity and forest management effects in hedonic pricing models for rural Nepal. J For Econ 27: 28-37. DOI 10.1016/j.jfe.2017.02.005.

Nerfa L, Rhemtulla JM, Zerriffi H. 2020. Forest dependence is more than forest income: Development of a new index of forest product collection and livelihood resources. World Dev 125: 104689. DOI 10.1016/j.worlddev.2019.104689.

Nielsen MR, Pouliot M, Bakkegaard RK. 2012. Combining income and assets measures to include the transitory nature of poverty in assessments of forest dependence: Evidence from the Democratic Republic of Congo. Ecol Econ 78: 37-46. DOI: 10.1016/j.ecolecon.2012.03.009.

Njurumana GN, Marsono D, Irham, Sadono R. 2014. Plant biodiversity conservation on Kaliwu system at Sumba Island. Manusia dan Lingkungan 21 (1): 75-82. DOI: 10.22146/jml.18514. [Indonesian]

Njurumana GN. 2016. Village community and flora biodiversity management in home garden system at central of Sumba regency.
Jurnal Penelitian Kehutanan Wallacea 5 (1): 1-12. DOI: 10.18330/jwallacea.2016.vol5iss1pp25-36. [Indonesian]

Njurumana GN. 2019. Provision services of biodiversity on Kaliwu agroforest system. Jurnal Pemuliaan Tanaman Hutan 13 (2): 123-132. DOI: $10.20886 /$ jpth.2019.13.2.\%p. [Indonesian]

Njurumana GN, Octavia D. 2020. Conservation of NTFPs species through agroforestry for community livelihoods in Sikka, East Nusa Tenggara. J Sylva Indonesiana 3 (1): 1-16. DOI: 10.32734/jsi.v3i01.1984. [Indonesian]

Oli BN, Treue T, Smith-Hall C.2016. The relative importance of community forests, government forests, and private forests for household-level incomes in the Middle Hills of Nepal. For Policy Econ 70: 155-163. DOI: 10.1016/j.forpol.2016.06.026

Parajuli R, Lamichhane D, Joshi O.2015. Does Nepal's community forestry program improve the rural household economy? A costbenefit analysis of community forestry user groups in Kaski and Syangja districts of Nepal. J For Res 20 (6): 475-483. DOI: 10.1007/s10310-015-0501-6.

Paudel J. 2018. Community-managed forests, household fuelwood use and food consumption. Ecol Econ 147: 62-73. DOI: 10.1016/j.ecolecon.2018.01.003.

Pearce F. 2011. Conservation and poverty reduction. Conserv Mag. www.conservationmagazine.org/2014/02/conservation-and-poverty/.

Phimmavonga S, Keenanb RJ. 2020. Forest plantation development, poverty, and inequality in Laos: A dynamic CGE microsimulation analysis. For Pol Econ 111: $102055 . \quad$ DOI: 10.1016/j.forpol.2019.102055.

Poudel DP. 2019. Migration, forest management and traditional institutions: Acceptance of and resistance to community forestry models in Nepal. Geoforum 106: 275-286. DOI: 10.1016/j.geoforum.2019.09.003.

Rakatama A, Pandit R. 2020. Reviewing social forestry schemes in Indonesia: Opportunities and challenges. For Pol Econ 111: 102052. DOI: $10.1016 /$ j.forpol.2019.102052.

Rasmussen LV, Watkins C, Agrawal A. 2017. Forest contributions to livelihoods in changing agriculture-forest landscapes. For Pol Econ 84: 1-8. DOI: 10.1016/j.forpol.2017.04.010.

RKU. 2017. Rencana Kerja Usaha HKm Tuartana Periode 2017-2027. Direktorat Jenderal Perhutanan Sosial dan Kemitraan Lingkungan, Kementerian Lingkungan Hidup dan Kehutanan, Jakarta. [Indonesian]

Sewel SJ, Desai SA, Mutsaa E, Lottering RT.2020. A comparative study of community perceptions regarding the role of roads as a poverty alleviation strategy in rural areas. J Rural Stud 71: 73-84. DOI: 10.1016/j.jrurstud.2019.09.001

Shackleton CM, Shackleton SE, Buiten E, Bird N. 2007. The importance of dry woodlands and forest in rural livelihoods and poverty alleviation in South Africa. For Policy Econ 9 (5): 558-577. DOI: 10.1016/j.forpol.2006.03.004.

Slamet DS, Tarkotjo I. 1980. Majalah Gizi dan Makanan. Pusat Penelitian dan Pengembangan Kesehatan Depkes RI, Jakarta. [Indonesian]

Susilowati SH, Maulana M. 2012. Luas lahan usahatani dan kesejateraan petani: eksistensi petani gurem dan urgensi kebijakan reforma agraria. Analisis Kebijakan Pertanian 10 (1): 17-30. DOI: 10.21082/akp.v10n1.2012.17-30.

Sunderland TCH, O'Connor A, Muir G, Nerfa L, Nodari GR, Wildmark C, Bahar N, Ickowitz A. 2019. SDG 2: Zero Hunger - Challenging the Hegemony of Monoculture Agriculture for Forests and People. In: Pierce CCJ, Winkel G, Galloway G, Pacheco P, Katila P, De Jong W. (eds) Sustainable Development Goals: Their Impacts on Forests and People. Cambridge University Press, Cambridge. DOI: $10.1017 / 9781108765015$.

Suprapti L. 2005. Teknologi Pengolahan Pangan Tepung Tapioka dan Pemanfaatannya. PT. Gramedia Pustaka, Jakarta. [Indonesian]

Tamang B, Sarkar BC, Pala NA, Shukla G, Vineeta, Patra PS, Bhat JA, Dey AN, Chakravarty S. 2019. Uses and ecosystem services of trees outside forest (TOF)-A case study from Uttar Banga Krishi Viswavidyalaya, West Bengal, India. Acta Ecol Sin 39: 431-437. DOI: 10.1016/j.chnaes.2018.09.017

Tsujinoa R, Yumotoa T, Kitamura S, Djamaluddin I, Darnaedi D. 2016. History of forest loss and degradation in Indonesia. Land Use Pol 57: 335-347. DOI: 10.1016/j.landusepol.2016.05.034.

Twala C. 2012. The impact of rural development on poverty reduction in a post-apartheid South Africa: An ecological discourse. J Hum Ecol 40 (3): 213-221. DOI: 10.1080/09709274.2012.11906539.

Umaya R, Hardjanto, Soekmadi R, Sunito S. 2020. Direct economic benefits and human dependence toward Gunung Merapi National 
Park, Indonesia. Biodiversitas 21 (3): 982-993. DOI: 10.13057/biodiv/d210318.

Uprety Y, Poudel RC, Gurung J, Chettri N, Chaudhary RP. 2016 Traditional use and management of NTFPs in Kangchenjunga Landscape: implications for conservation and livelihoods. J Ethnobiol Ethnomed 12 (19): 1-59. DOI: 10.1186/s13002-016-0089-8.

Vedeld P, Angelsen A, BojÖ J, Sjaastad E, Berg GK. 2007. Fores environmental incomes and the rural poor. For Policy Econ 9 (7): 869-879. DOI: 10.1016/j.forpol.2006.05.008.

Vira B, Wildburger C, Mansourian S. 2015. Forests, trees and landscapes for food security and nutrition. a global assessment report. In: Vira B Wildburger C, Mansourian S (eds.). IUFRO World Series. International Union of Forest Research Organizations (IUFRO), Vienna.

Wollenberg E, Belcher B, Sheil D, Dewi S, Moeliono M. 2004. Mengapa kawasan hutan penting bagi penanggulangan kemiskinan di Indonesia? CIFOR Governance Brief, Bogor. [Indonesian]
Wunder S, Angelsen A, Belcher B. 2014. Forests, livelihoods, and conservation: broadening the empirical base. World Dev 64: 1-11. DOI: 10.1016/j.worlddev.2014.03.007.

Xu J, Song J, Li B, Liu D, Wei D, Cao X. 2020. Do settlements isolation and land-use changes affect poverty? Evidence from a mountainous province of China. J Rural Stud 76: 163-172. DOI: 10.1016/j.jrurstud.2020.04.018.

Yamamoto Y, Shigetomi Y, Ishimura Y, Hattori M.2019. Forest change and agricultural productivity: Evidence from Indonesia. World Dev 114: 196-207. DOI: 10.1016/j.worlddev.2018.10.001.

Yang X, Xu J, Xu X, Yi Y, Hyde WF. 2020. Collective forest tenure reform and household energy consumption: A case study in Yunnan Province, China. China Econ Rev 60: 101134. DOI: 10.1016/j.chieco.2017.12.001. 